\title{
A Study of the Crystal Structure and Hydrogen Bonding of 3-Trifluoroacetyloxime Substituted 7-Acetamido-2-aryl-5-bromoindoles
}

\author{
Malose J. Mphahlele ${ }^{\mathbb{1}}$ \\ Department of Chemistry, College of Science, Engineering and Technology, University of South Africa, \\ Private Bag X06, Florida 1710, South Africa; mphahmj@unisa.ac.za; Tel.: +27-11-670-9301 \\ Received: 5 June 2018; Accepted: 26 June 2018; Published: 29 June 2018

\begin{abstract}
The 7-acetyl-2-aryl-5-bromo-3-(trifluoroacetyl)indoles 1a-d were reacted with hydroxylamine hydrochloride (2.2 equiv.) in the presence of pyridine in ethanol under reflux to afford the corresponding diketo oxime derivatives 2a-d. Beckmann rearrangement of the latter with trifluoroacetic acid under reflux afforded the corresponding 7-acetamido-2-aryl-5-bromo-3-(trifluoroacetyloxime)indoles 3a-d. The structures of the prepared compounds were characterized using a combination of NMR $\left({ }^{1} \mathrm{H} \&{ }^{13} \mathrm{C}\right), \mathrm{IR}$, and mass spectrometric techniques. The molecular structure of the 3-trifluoroacetyloxime substituted 7-acetamido-2-aryl-5-bromoindoles was unambiguously confirmed by the single crystal X-ray diffraction data of $\mathbf{3 d}$. Structural studies of $\mathbf{3 d}$ in the solid state by X-ray crystallography provided evidence of hydrogen bonding networks and $\pi$-stacking of the indole moiety. Compound $3 \mathbf{d}$ was crystallized in the trigonal space group R-3:H with unit cell dimensions a $=25.1614(13)$, $\mathrm{b}=25.1614(13), \mathrm{c}=17.3032(9) \AA, \alpha=\beta=90^{\circ}, \gamma=120^{\circ}, \mathrm{V}=9486.9(11) \AA^{3}, \mathrm{Z}=6$. The density functional theory (DFT) structural parameters (bond lengths, bond angles, and torsion angles) of the optimized geometry calculated using the B3LYP/6-311G basis set were found to compare favourably with those of the X-ray crystal structure.
\end{abstract}

Keywords: 7-acetyl-2-aryl-5-bromo-3-(trifluoroacetyl)indoles; oximation; Beckmann rearrangement; hydrogen bonds; XRD; DFT

\section{Introduction}

The chemistry of indole- and isatin-based oximes has been the subject of numerous studies due to their interesting chemical and biological applications [1]. Oximes generally act as dual hydrogen-bond donors via the $-\mathrm{O}-\mathrm{H}$ moiety and hydrogen-bond acceptors via the $-\mathrm{C}=\mathrm{N}$ and the $-\mathrm{OH}$ moieties. They are capable of forming dimers as well as oxime-oxime catemers via $\mathrm{O}-\mathrm{H} \cdots \mathrm{N}=\mathrm{C}$ and $\mathrm{O}-\mathrm{H} \cdots \mathrm{OH}$ hydrogen-bonds in the solid-state [2]. Hydrogen bonding plays an important role in drug-receptor interactions, and drug design in chemical and biological processes as well as molecular recognition and the bioactivity of macromolecules [3]. Hydrogen bond formation causes changes in the distances between atoms and the rearrangement of electron densities on the groups involved in the interaction and therefore chemical reactivity of the reaction centres that are directly involved in the hydrogen bonding [4]. Structure-activity relationship (SAR) studies of the polysubstituted indoles revealed that an acetyl or formyl group on C-3 of the indole framework facilitates the interaction with biological receptors and therefore enhances anticancer activity [5]. We evaluated the 3-trifluoroacetyl-substituted 7-acetyl- and 7-acetamido-2-aryl-5-bromoindoles as well as their corresponding C-3 unsubstituted precursors for antigrowth properties against the A549 and HeLa cell lines and for their ability to inhibit tubulin polymerization [6]. Only the 3-trifluoroacetyl substituted 7-acetamido-2-aryl-3-bromoindoles 
were found to exhibit significant cytotoxicity against the two cancer cell lines and also to inhibit tubulin polymerization. Molecular docking (in silico) of the 2-aryl-5-bromo-3-(trifluoroacetyl)indoles into the colchicine-binding domain of $\alpha, \beta$-tubulin interface predicted the presence of a hydrogen bond between the the amide and 3-trifluoroacetyl moieties with some of the protein residues [6]. The propensity of the amide moiety to serve as a dual hydrogen-bond donor and acceptor plays a significant role in the interaction of bioactive compounds with the receptors [4,7]. A thorough knowledge of hydrogen bond interaction, on the other hand, helps in understanding the chemical properties of organic compounds and bio-macromolecules [8]. Recourse to the literature revealed a paper describing the transformation of a series of $\alpha$-trifluoromethylated ketoximes to afford optically active $\alpha$-trifluoromethylated amines, which are important sources of fluorinated pharmaceuticals [9]. We considered the cytotoxicity of the 2-arylindole derivatives $[5,6,10]$ in combination with the literature SAR analyses on indole oximes [1] to transform the strong hydrogen bond accepting trifluoroacetyl group into dual hydrogen-bond donating and accepting $\alpha$-trifluoromethylated ketoxime function based on the 7-acetyl-2-aryl-3-bromoindole as substrates. The main aim was to study the molecular structure and hydrogen bonding potential of the resultant 3-trifluoroacetyloxime substituted 7-acetamido-2-aryl-3-bromoindole derivatives in the solid state by means of single crystal X-ray diffraction (XRD) technique. The optimized structural parameters (bond lengths, bond angles, and torsion angles) were also investigated by means of density functional theory (DFT) calculations and have been compared with those of the X-ray structure.

\section{Materials and Methods}

\subsection{General Notes}

The melting point values of the prepared compounds were recorded on a Thermocouple digital melting point apparatus and their IR spectra were recorded using a Bruker VERTEX 70 FT-IR Spectrometer (Bruker Optics, Billerica, MA, USA) with a diamond ATR (attenuated total reflectance) accessory by using the thin-film method. Merck kieselgel $60(0.063-0.200 \mathrm{~mm})$ (Merck KGaA, Frankfurt, Germany) was used as stationary phase for column chromatography. The proton and carbon-13 NMR spectra were obtained as DMSO- $d_{6}$ solutions using Agilent $300 \mathrm{MHz}$ NMR (Agilent Technologies, Oxford, UK) spectrometer and the chemical shifts are quoted relative to the TMS peak. The low- and high-resolution mass spectra were recorded at an ionization potential of $70 \mathrm{eV}$ using Waters Synapt G2 Quadrupole Time-of-flight mass spectrometer (Waters Corp., Milford, MA, USA). Compounds 1a-d were prepared as described in our previous investigation [6].

\subsection{Typical Procedure for the Synthesis of Diketoximes 2a-d}

A stirred mixture of 1a-d (1 equivalent) and hydroxylamine hydrochloride (2.5 equivalent) in pyridine $(30 \mathrm{~mL} / \mathrm{mmol}$ of $1 \mathrm{a}-\mathbf{d})$ was heated at $80{ }^{\circ} \mathrm{C}$ for $12 \mathrm{~h}$. The mixture was cooled to room temperature (RT) and quenched with an ice-cold water and the product was extracted into chloroform. The combined organic layers were washed with water and dried over anhydrous $\mathrm{MgSO}_{4}$. The salt was filtered off and the solvent was evaporated under reduced pressure on a rotary evaporator. The residue was purified by column chromatography on silica gel using $20 \%$ EtOAc-hexane mixture as eluent to afford the diketoximes $\mathbf{2 a - d}$. The following compounds were prepared in this fashion [11].

\subsection{1. (E/Z)-1-[5-Bromo-7-(1-hydroxyiminoethyl)-2-phenyl-1H-indol-3-yl]-2,2,2-trifluoroethanone oxime (2a)}

A mixture of $1 \mathrm{a}(0.50 \mathrm{~g}, 1.22 \mathrm{mmol})$, hydroxylamine hydrochloride $(0.21 \mathrm{~g}, 3.05 \mathrm{mmol})$ in pyridine $(40 \mathrm{~mL})$ afforded $2 \mathbf{a}\left(E \&\right.$ Z-isomers) as a solid $(77 \mathrm{~g}, 0.41 \%), R_{f} 0.36$; m.p. $223-226{ }^{\circ} \mathrm{C} ; v_{\max }$ (ATR) 502, 538, 569, 618, 648, 684, 737, 773, 826, 916, 970, 1011, 1082, 1156, 1206, 1318, 1343, 1398, 1464, 1501, 1531, 1553, 1634, 3243, 3299, 3391, $3446 \mathrm{~cm}^{-1} ;{ }^{1} \mathrm{H}-\mathrm{NMR}$ (DMSO-d 6 ) $2.31\left(\mathrm{H}, \mathrm{s}, \mathrm{CH}_{3}\right), 7.43-7.62$ $(7 \mathrm{H}, \mathrm{m}, \mathrm{Ar}), 11.14 \& 11.20(1 \mathrm{H}, \mathrm{s}, \mathrm{NH}), 11.65(1 \mathrm{H}, \mathrm{s}, \mathrm{OH}), 12.90$ and $13.06(1 \mathrm{H}, \mathrm{s}, \mathrm{OH}) ;{ }^{13} \mathrm{C}-\mathrm{NMR}$ $\left(\right.$ DMSO- $\left.d_{6}\right) 11.50,98.9 \& 102.6,113.4 \& 113.6,118.8\left(\mathrm{q},{ }^{1} J=280.6 \mathrm{~Hz}\right)$ and $121.6\left(\mathrm{q},{ }^{1} J=273.7 \mathrm{~Hz}\right), 121.7$, $122.1 \& 122.7,124.2 \& 124.3,127.3 \& 128.2,129.4 \& 129.6,129.5,130.8,131.1 \& 131.2,131.6,139.0 \& 140.2$, 
$140.4\left(q,{ }^{2} J=31.0 \mathrm{~Hz}\right) \& 142.0\left(\mathrm{q},{ }^{2} J=32.1 \mathrm{~Hz}\right), 153.7$ \& 153.8; HRMS (ES): $\mathrm{MH}^{+}$, found: 440.0229 . $\mathrm{C}_{18} \mathrm{H}_{14} \mathrm{~N}_{3} \mathrm{O}_{2} \mathrm{~F}_{3}{ }^{79} \mathrm{Br}^{+}$requires: 440.0221 .

2.2.2. (E/Z)-1-[5-Bromo-2-(4-fluorophenyl)-7-(1-hydroxyiminoethyl)-1H-indol-3-yl]-2,2,2-trifluoroethanone oxime (2b)

A mixture of $\mathbf{1 b}(0.30 \mathrm{~g}, 0.65 \mathrm{mmol})$ and hydroxylamine hydrochloride $(0.11 \mathrm{~g}, 1.45 \mathrm{mmol})$ in pyridine $(40 \mathrm{~mL})$ afforded $\mathbf{2 b}$ as solid $(0.21 \mathrm{~g}, 70 \%) ; R_{f} 0.52 ; \mathrm{m} . \mathrm{p} .288-291{ }^{\circ} \mathrm{C} ; v_{\max }$ (ATR) 516 , 537, 571, 694, 728, 832, 893, 946, 967, 989, 1011, 1131, 1162, 1184, 1234, 1323, 1373, 1441, 1470, 1506, 1531, 1574, 1652, 3063, 3188, $3411 \mathrm{~cm}^{-1} ;{ }^{1} \mathrm{H}-\mathrm{NMR}$ (DMSO-d $) 2.15\left(3 \mathrm{H}, \mathrm{s}, \mathrm{CH}_{3}\right), 7.13(1 \mathrm{H}, \mathrm{d}$, $J=1.8 \mathrm{~Hz}, \mathrm{H}-4), 7.39\left(2 \mathrm{H}, \mathrm{t}, J=9.0 \mathrm{~Hz}, \mathrm{H}-3^{\prime}, 5^{\prime}\right), 7.57\left(2 \mathrm{H}, \mathrm{t}, J=9.0 \mathrm{~Hz}, \mathrm{H}-2^{\prime}, 6^{\prime}\right), 7.85(1 \mathrm{H}, \mathrm{d}, J=1.8 \mathrm{~Hz}$, $\mathrm{H}-6), 9.78(1 \mathrm{H}, \mathrm{s}, \mathrm{NH}), 11.71(1 \mathrm{H}, \mathrm{s}, \mathrm{NH}), 12.82(1 \mathrm{H}, \mathrm{s}, \mathrm{OH}) ;{ }^{13} \mathrm{C}-\mathrm{NMR}$ (DMSO-d $\left.{ }_{6}\right) 24.4,98.8,113.0$, $116.6\left(\mathrm{~d},{ }^{2} J_{\mathrm{CF}}=21.8 \mathrm{~Hz}\right), 116.8,117.0,121.8\left(\mathrm{q},{ }^{1} J_{\mathrm{CF}}=272.6 \mathrm{~Hz}\right), 125.8,127.0,128.0\left(\mathrm{~d},{ }^{4} J_{\mathrm{CF}}=3.5 \mathrm{~Hz}\right)$, $129.6,129.7\left(\mathrm{~d},{ }^{3} J_{\mathrm{CF}}=8.0 \mathrm{~Hz}\right), 137.8,142.0\left(\mathrm{q},{ }^{2} J_{\mathrm{CF}}=32.2 \mathrm{~Hz}\right), 163.0\left(\mathrm{~d},{ }^{1} J_{\mathrm{CF}}=245.1 \mathrm{~Hz}\right), 169.3$; HRMS (ES): $\mathrm{MH}^{+}$, found: $458.0130 . \mathrm{C}_{18} \mathrm{H}_{13} \mathrm{~N}_{3} \mathrm{O}_{2} \mathrm{~F}_{4}{ }^{79} \mathrm{Br}^{+}$requires: 458.0127 .

2.2.3. (E/Z)-1-[5-Bromo-2-(3-chloro-phenyl)-7-(1-hydroxyiminoethyl)-1H-indol-3-yl]-2,2,2-trifluoroethanone oxime (2c)

A mixture of $1 \mathrm{c}(0.50 \mathrm{~g}, 1.12 \mathrm{mmol})$ and hydroxylamine hydrochloride $(0.20 \mathrm{~g}, 2.81 \mathrm{mmol})$ in pyridine $(40 \mathrm{~mL})$ afforded $2 \mathrm{c}\left(E \& \mathrm{Z}\right.$-isomers) as a solid $(0.35 \mathrm{~g}, 66 \%), R_{f} 0.22 ; \mathrm{m} . \mathrm{p} . \quad 228-230{ }^{\circ} \mathrm{C}$; $v_{\max }$ (ATR) 582, 624, 670, 681, 735, 783, 811, 851, 929, 953, 973, 1017, 1077, 1096, 1152, 1178, 1258, 1289, $1319,1376,1432,1462,1601,3239,3284,3385 \mathrm{~cm}^{-1} ;{ }^{1} \mathrm{H}-\mathrm{NMR}$ (DMSO-d $\left.d_{6}\right) 2.23\left(\mathrm{H}, \mathrm{s}, \mathrm{CH}_{3}\right), 7.38-7.59(6 \mathrm{H}$, $\mathrm{m}, \mathrm{Ar}), 11.20$ and $11.26(1 \mathrm{H}, \mathrm{s}, \mathrm{NH}), 11.55(1 \mathrm{H}, \mathrm{s}, \mathrm{OH}), 12.92$ and $13.05(1 \mathrm{H}, \mathrm{s}, \mathrm{OH}) ;{ }^{13} \mathrm{C}-\mathrm{NMR}\left(\mathrm{DMSO}-d_{6}\right)$ 11.60, 98.9 and 103.2, 113.4 and 113.6, $118.6\left(\mathrm{q},{ }^{1} \mathrm{~J}=281.7 \mathrm{~Hz}\right), 121.7$ and 121.9, 123.0, 124.4 and 124.5, 126.0, 127.0, 127.9, 129.2, 130.4, 131.2 and 131.6, 133.1, 134.0, 137.4 and 138.5, $140.0\left(\mathrm{q},{ }^{2} \mathrm{~J}=30.8 \mathrm{~Hz}\right)$ and $141.5\left(\mathrm{q},{ }^{2} \mathrm{~J}=31.6 \mathrm{~Hz}\right), 153.4$; HRMS (ES): $\mathrm{MH}^{+}$, found: 473.9833. $\mathrm{C}_{18} \mathrm{H}_{13} \mathrm{~N}_{3} \mathrm{O}_{2} \mathrm{~F}_{3}{ }^{35} \mathrm{Cl}^{79} \mathrm{Br}^{+}$ requires: 473.9832 .

2.2.4. (E/Z)-1-[5-Bromo-7-(1-hydroxyiminoethyl)-2-(4-methoxyphenyl)-1H-indol-3-yl]-2,2,2-trifluoroethanone oxime (2d)

A mixture of $1 \mathbf{d}(0.50 \mathrm{~g}, 1.14 \mathrm{mmol})$ and hydroxylamine hydrochloride $(0.20 \mathrm{~g}, 2.84 \mathrm{mmol})$ in pyridine $(40 \mathrm{~mL})$ afforded $2 \mathrm{~d}\left(E \& \mathrm{Z}\right.$-isomers) as a solid $(0.35 \mathrm{~g}, 66 \%), R_{f} 0.23$; m.p. $211-213{ }^{\circ} \mathrm{C}$; $v_{\max }$ (ATR) 516, 570, 611, 662, 738, 770, 775, 829, 844, 918, 970, 1032, 1074, 1151, 1175, 1204, 1258, 1287, 1324, 1435, 1466, 1514, 1613, 3237, 3277, $3398 \mathrm{~cm}^{-1}$; ${ }^{1} \mathrm{H}-\mathrm{NMR}$ (DMSO-d $) 2.30\left(3 \mathrm{H}, \mathrm{s}, \mathrm{CH}_{3}\right), 3.80(3 \mathrm{H}, \mathrm{s}$, $\left.\mathrm{OCH}_{3}\right), 7.09\left(2 \mathrm{H}, \mathrm{d}, J=8.7 \mathrm{~Hz}, \mathrm{H}-3^{\prime}, 5^{\prime}\right), 7.50-7.53(4 \mathrm{H}, \mathrm{m}, \mathrm{Ar}), 11.00 \& 11.04(1 \mathrm{H}, \mathrm{s}, \mathrm{NH}), 11.61(1 \mathrm{H}, \mathrm{s}$, $\mathrm{OH}), 12.80$ and $12.82(1 \mathrm{H}, \mathrm{s}, \mathrm{OH}) ;{ }^{13} \mathrm{C}-\mathrm{NMR}\left(\mathrm{DMSO}_{-} \mathrm{d}_{6}\right) 11.4,55.8,97.9$ and $101.7,113.4$ and $114.9,118.8$ $\left(\mathrm{q},{ }^{1} J=281.7 \mathrm{~Hz}\right), 121.5$ and $121.8,122.4,123.4$ and $123.5,123.8$ and $124.0,128.7$ and $129.5,130.0,130.9$ and 131.1, 131.4, 139.1 and $140.3,140.6\left(\mathrm{q},{ }^{2} J=30.0 \mathrm{~Hz}\right)$ and $142.2\left(\mathrm{q},{ }^{2} J=32.0 \mathrm{~Hz}\right), 153.7$ and 153.8 , 160.3 and 160.4; HRMS (ES): $\mathrm{MH}^{+}$, found: $470.0331 . \mathrm{C}_{19} \mathrm{H}_{16} \mathrm{~N}_{3} \mathrm{O}_{3} \mathrm{~F}_{3}{ }^{79} \mathrm{Br}^{+}$requires: 470.0327 .

\subsection{Typical Procedure for the Beckmann Rearrangement of $\mathbf{2 a - d}$ into $\mathbf{3 a - d}$}

A stirred mixture of 2 ( 1 equivalent) and TFA ( 2 equivalent) in acetonitrile ( $30 \mathrm{~mL} / \mathrm{mmol}$ of 2 ) was heated at $80^{\circ} \mathrm{C}$ for $2 \mathrm{~h}$. The mixture was cooled to RT, quenched with an ice-cold water and the product was extracted with chloroform $(3 \times 20 \mathrm{~mL})$. The combined organic layers were dried over anhydrous $\mathrm{MgSO}_{4}$ and the salt was filtered off. The solvent was evaporated under reduced pressure and the residue was purified by column chromatography on a silica gel using $60 \%$ EtOAc-hexane mixture as an eluent to afford 3 as a solid [11]. The following products were prepared in this fashion:

\subsection{1. $N$-[5-Bromo-2-phenyl-3-(2,2,2-trifluoro-1-hydroxyiminoethyl)-1H-indol-7-yl]acetamide (3a)}

A mixture of $2 \mathbf{a}(0.30 \mathrm{~g}, 0.68 \mathrm{mmol})$ and TFA $(0.16 \mathrm{~g}, 1.36 \mathrm{mmol})$ in acetonitrile $(20 \mathrm{~mL})$ afforded 3a as solid (0.22 g, 73\%); $R_{f} 0.50$; m.p. $249-252{ }^{\circ} \mathrm{C} ; v_{\max }$ (ATR) 531, 585, 603, 691, 728, 764, 844, 892, 
$908,1143,1166,1199,1222,1328,1368,1404,1452,1468,1545,1645,3058,3204,3343 \mathrm{~cm}^{-1} ;{ }^{1} \mathrm{H}-\mathrm{NMR}$ (DMSO- $\left.d_{6}\right) 2.15\left(3 \mathrm{H}, \mathrm{s}, \mathrm{CH}_{3}\right), 7.10(1 \mathrm{H}, \mathrm{d}, J=1.8 \mathrm{~Hz}, \mathrm{H}-4), 7.51-7.55(5 \mathrm{H}, \mathrm{m}, \mathrm{Ph}), 7.86(1 \mathrm{H}, \mathrm{d}, J=1.8 \mathrm{~Hz}$, 6-H), $9.79(1 \mathrm{H}, \mathrm{s}, \mathrm{NH}), 11.72(1 \mathrm{H}, \mathrm{s}, \mathrm{NH}), 12.80(1 \mathrm{H}, \mathrm{s}, \mathrm{OH}) ;{ }^{13} \mathrm{C}-\mathrm{NMR}$ (DMSO-d 6 ) 24.4, 98.8, 113.1, 116.6, 116.9, $121.7\left(\mathrm{q},{ }^{1} J_{\mathrm{CF}}=272.6 \mathrm{~Hz}\right), 125.9,126.9,127.4,129.5,129.6,129.7,131.4,138.7,142.1(\mathrm{q}$, ${ }^{2} J_{\mathrm{CF}}=33.2 \mathrm{~Hz}$ ), 169.3; HRMS (ES): $\mathrm{MH}^{+}$, found: 440.0210. $\mathrm{C}_{18} \mathrm{H}_{14} \mathrm{~N}_{3} \mathrm{O}_{2} \mathrm{~F}_{3}{ }^{79} \mathrm{Br}^{+}$requires: 440.0221 .

2.3.2. N-[5-Bromo-2-(4-fluorophenyl)-3-(2,2,2-trifluoro-1-hydroxyiminoethyl)-1H-indol-7-yl]acetamide (3b)

A mixture of $2 \mathbf{b}(0.30 \mathrm{~g}, 0.65 \mathrm{mmol})$ and TFA $(0.15 \mathrm{~g}, 1.31 \mathrm{mmol})$ in acetonitrile $(20 \mathrm{~mL})$ afforded $3 \mathbf{b}$ as solid $(0.21 \mathrm{~g}, 70 \%) ; R_{f} 0.52$; m.p. $288-291^{\circ} \mathrm{C} ; v_{\max }$ (ATR) 516, 537, 571, 694, 728, 832, 893, 946, 967, 989, 1011, 1131, 1162, 1184, 1234, 1323, 1373, 1441, 1470, 1506, 1531, 1574, 1652, 3063, 3188, $3411 \mathrm{~cm}^{-1}$; ${ }^{1} \mathrm{H}-\mathrm{NMR}\left(\mathrm{DMSO}-d_{6}\right) 2.15\left(3 \mathrm{H}, \mathrm{s}, \mathrm{CH}_{3}\right), 7.13(1 \mathrm{H}, \mathrm{d}, J=1.8 \mathrm{~Hz}, \mathrm{H}-4), 7.39\left(2 \mathrm{H}, \mathrm{t}, J=9.0 \mathrm{~Hz}, \mathrm{H}-3^{\prime}, 5^{\prime}\right)$, 7.55-7.60 (2H, dd, $J=5.5$ and $\left.8.5 \mathrm{~Hz}, \mathrm{H}-2^{\prime}, 6^{\prime}\right), 7.85(1 \mathrm{H}, \mathrm{d}, J=1.8 \mathrm{~Hz}, \mathrm{H}-6), 9.78(1 \mathrm{H}, \mathrm{s}, \mathrm{NH}), 11.71$ $(1 \mathrm{H}, \mathrm{s}, \mathrm{NH}), 12.82(1 \mathrm{H}, \mathrm{s}, \mathrm{OH}) ;{ }^{13} \mathrm{C}-\mathrm{NMR}\left(\mathrm{DMSO}-d_{6}\right) 24.4,98.8,113.0,116.6\left(\mathrm{~d},{ }^{2} J_{\mathrm{CF}}=21.8 \mathrm{~Hz}\right), 116.8$, $117.0,121.8\left(\mathrm{q},{ }^{1} J_{\mathrm{CF}}=272.6 \mathrm{~Hz}\right), 125.8,127.0,128.0\left(\mathrm{~d},{ }^{4} J_{\mathrm{CF}}=3.5 \mathrm{~Hz}\right), 129.6,129.7\left(\mathrm{~d},{ }^{3} J_{\mathrm{CF}}=8.0 \mathrm{~Hz}\right)$, 137.8, $142.0\left(\mathrm{q},{ }^{2} J_{\mathrm{CF}}=32.2 \mathrm{~Hz}\right), 163.0\left(\mathrm{~d},{ }^{1} J_{\mathrm{CF}}=245.1 \mathrm{~Hz}\right), 169.3$; HRMS (ES): $\mathrm{MH}^{+}$, found: 458.0130 . $\mathrm{C}_{18} \mathrm{H}_{13} \mathrm{~N}_{3} \mathrm{O}_{2} \mathrm{~F}_{4}{ }^{79} \mathrm{Br}^{+}$requires: 458.0127 .

2.3.3. N-[5-Bromo-2-(3-chlorophenyl)-3-(2,2,2-trifluoro-1-hydroxyiminoethyl)-1H-indol-7-yl]acetamide (3c)

A mixture of $2 \mathbf{c}(0.30 \mathrm{~g}, 0.63 \mathrm{mmol})$ and TFA $(0.14 \mathrm{~g}, 1.26 \mathrm{mmol})$ in acetonitrile $(20 \mathrm{~mL})$ afforded 3 c as solid $(0.21 \mathrm{~g}, 70 \%) ; R_{f} 0.50$; m.p. $280-283^{\circ} \mathrm{C}$; $v_{\max }$ (ATR) 490, 517, 533, 573, 680, 737, 761, 790, 836, 892, 953, 986, 1061, 1134, 1156, 1189, 1211, 1292, 1322, 1448, 1506, 1544, 1647, 3060, 3219, $3374 \mathrm{~cm}^{-1}$; ${ }^{1} \mathrm{H}-\mathrm{NMR}\left(\mathrm{DMSO}-d_{6}\right) 2.16\left(3 \mathrm{H}, \mathrm{s}, \mathrm{CH}_{3}\right), 7.15(1 \mathrm{H}, \mathrm{d}, J=1.8 \mathrm{~Hz}, \mathrm{H}-4), 7.47-7.60(4 \mathrm{H}, \mathrm{m}, \mathrm{Ar}), 7.86(1 \mathrm{H}, \mathrm{d}$, $J=1.8 \mathrm{~Hz}, \mathrm{H}-6), 9.78(1 \mathrm{H}, \mathrm{s}, \mathrm{NH}), 11.77(1 \mathrm{H}, \mathrm{s}, \mathrm{NH}), 12.90(1 \mathrm{H}, \mathrm{s}, \mathrm{OH}) ;{ }^{13} \mathrm{C}-\mathrm{NMR}$ (DMSO-d 6 ) 24.4, 99.5, $113.2,117.1,117.2,121.7\left(\mathrm{q},{ }^{1} J_{\mathrm{CF}}=272.6 \mathrm{~Hz}\right), 125.9,126.1,126.9,127.2,129.3,129.5,131.5,133.4,134.1$, 136.9, $141.8\left(\mathrm{q},{ }^{2} \mathrm{~J}_{\mathrm{CF}}=33.2 \mathrm{~Hz}\right), 169.2$; HRMS (ES): $\mathrm{MH}^{+}$, found: $473.9829 . \mathrm{C}_{18} \mathrm{H}_{13} \mathrm{~N}_{3} \mathrm{O}_{2} \mathrm{~F}_{3}{ }^{35} \mathrm{Cl}^{79} \mathrm{Br}^{+}$ requires: 473.9832 .

2.3.4. N-[5-Bromo-2-(4-methoxyphenyl)-3-(2,2,2-trifluoro-1-hydroxyiminoethyl)-1H-indol-7-yl]acetamide (3d)

A mixture of $2 \mathbf{d}(0.30 \mathrm{~g}, 0.64 \mathrm{mmol})$ and TFA $(0.15 \mathrm{~g}, 1.28 \mathrm{mmol})$ in acetonitrile $(20 \mathrm{~mL})$ afforded 3d as solid (0.19 g, 65\%); $R_{f} 0.37$; m.p. $264-266^{\circ} \mathrm{C}$; $v_{\max }$ (ATR) 524, 577, 594, 736, 755, 831, 892, 948, 966, 985, 1031, 1138, 1174, 1195, 1254, 1306, 1326, 1368, 1401, 1433, 1465, 1505, 1546, 1610, 3004, 3126, $3295 \mathrm{~cm}^{-1}$; ${ }^{1} \mathrm{H}-\mathrm{NMR}$ (DMSO-d $\left.\mathrm{d}_{6}\right) 2.17\left(3 \mathrm{H}, \mathrm{s}, \mathrm{CH}_{3}\right), 3.80\left(3 \mathrm{H}, \mathrm{s}, \mathrm{CH}_{3}\right), 7.09(1 \mathrm{H}, \mathrm{d}, J=1.8 \mathrm{~Hz}, \mathrm{H}-4), 7.10$ $\left(2 \mathrm{H}, \mathrm{d}, J=8.7 \mathrm{~Hz}, \mathrm{H}-3^{\prime}, 5^{\prime}\right), 7.50\left(2 \mathrm{H}, \mathrm{d}, J=8.7 \mathrm{~Hz}, \mathrm{H}-2^{\prime}, 6^{\prime}\right), 7.87(1 \mathrm{H}, \mathrm{d}, J=1.8 \mathrm{~Hz}, \mathrm{H}-6), 9.79(1 \mathrm{H}, \mathrm{s}, \mathrm{NH})$, $11.61(1 \mathrm{H}, \mathrm{s}, \mathrm{NH}), 12.77(1 \mathrm{H}, \mathrm{s}, \mathrm{OH}) ;{ }^{13} \mathrm{C}-\mathrm{NMR}\left(\mathrm{DMSO}-d_{6}\right) 24.4,55.7,97.9,114.7\left(\mathrm{q},{ }^{1} J_{\mathrm{CF}}=288.5 \mathrm{~Hz}\right)$, 114.9 (2C), 116.7, 123.6, 123.7, 125.7, 126.6, 128.8, 129.8, 138.8, $142.2\left(\mathrm{q},{ }^{2} J_{\mathrm{CF}}=32.0 \mathrm{~Hz}\right), 160.3,169.2$; HRMS (ES): $\mathrm{MH}^{+}$, found: $470.0331 . \mathrm{C}_{19} \mathrm{H}_{16} \mathrm{~N}_{3} \mathrm{O}_{3} \mathrm{~F}_{3}{ }^{79} \mathrm{Br}^{+}$requires: 470.0327 .

\subsection{Data Collection and Refinement}

Intensity data was determined on a Bruker Venture D8 Photon CMOS diffractometer with graphite-monochromated $\mathrm{MoK} \alpha_{1}(\lambda=0.71073 \AA)$ radiation at $173 \mathrm{~K}$ using an Oxford Cryostream 600 cooler. Data reduction was carried out using the program SAINT+, version 6.02 [12] and face-indexed absorption corrections were made using the program XPREP [12]. Space group assignment was made using XPREP [11]. The structure was solved in the Win GX [13] suite of programs by means of direct methods through using SHELXS-97 [13]. The structure was refined using full-matrix least-squares/difference Fourier techniques on $F^{2}$ using SHELXL-2017 [14]. All C-H hydrogen atoms were placed at idealized positions and refined as riding atoms with isotropic parameters 1.2 times those of their parent atoms. All N- and O- bound hydrogen atoms were located in difference map and their coordinates and isotropic displacement parameters refined freely. The disorder of the trifluoroacetyl group was modelled by finding alternate positions for the two $\mathrm{CF}_{3}$ groups in the difference Fourier map. These were then refined anisotropically together with their site occupancies 
summed to one to final values of 0.660(19) and 0.340(19). The corresponding C-F bonded distance and the one-angle nonbonded distances were restrained to similar values, subject to s.u. values of 0.01 and $0.02 \mathrm{~A}$, respectively. The disorder of the chloroform solvent sitting on a special position was modelled by finding alternate positions for the $\mathrm{H}-\mathrm{C}-\mathrm{Cl}$ fragments and refining their anisotropic displacement parameters anisotropically and their occupancies to final values of $0.689(14)$ and $0.311(14)$. The corresponding $\mathrm{C}-\mathrm{Cl}$ bonded distance and the one-angle nonbonded distances were restrained to similar values, subject to s.u. values of 0.01 and $0.02 \mathrm{~A}$, respectively. Diagrams and publication material were generated using ORTEP-3 [13] and PLATON [15]. Details of the data collection conditions and the parameters of the refinement process are given in Table 2.

\subsection{Computational Methods}

The density functional theory (DFT) computations were carried out using the B3LYP exchange correlation functional [16], together with 6-311G [17,18] basis set for all atoms. All computations were performed using the Gaussian 09 software suite [19]. The geometrical optimizations were performed in the gas phase without solvent corrections because it was reported that gas phase calculations frequently correspond quite well with crystal structures [20].

\section{Results and Discussion}

\subsection{Synthesis}

The synthetic procedure for the title compounds is shown in Scheme 1. The 7-acetyl-2-aryl-5-bromo-3-(trifluoroacetyl)indoles 1a-d were subjected to hydroxylamine hydrochloride (2.2 equiv.) in the presence of pyridine in ethanol under reflux for $12 \mathrm{~h}$ (Scheme 1 ). We isolated the corresponding diketoxime derivatives $\mathbf{2 a - d}$ in high yield and purity by aqueous work-up and column chromatography on silica gel (Table 1 ). Both the ${ }^{1} \mathrm{H}$ - and ${ }^{13} \mathrm{C}-\mathrm{NMR}$ spectral data revealed the presence of additional peaks presumably due to different arrangement around the oxime moiety resulting from the known syn-anti isomerism [1]. The accurate calculated $m / z$ values for these compounds, nevertheless, represent in each case a closet fit consistent with the assigned molecular structures. Whereas the 2-arylindole-3-acetoximes undergo acid-mediated Beckmann rearrangement into 3-acetamido-2-arylindoles with ease [21], the analogous oximes derived from the trifluoroacetyl derivatives are generally stable towards rearrangement into amides [22]. With this literature precedent in mind, we subjected compounds 2a-d to trifluoroacetic acid-mediated Beckmann rearrangement under reflux for $2 \mathrm{~h}$ following the literature precedent [11]. Aqueous work-up and purification of the crude products by silica gel column chromatography afforded compounds characterized by means of NMR, IR, and mass spectrometric methods as the corresponding 3-trifluoroacetyloxime substituted 7-acetamido-2-aryl-5-bromoindole derivatives 3a-d. The latter are interesting because the $\alpha$-trifluoromethylated ketoximes can be tosylated or mesylated and then cyclized into the corresponding diaziridines [22-24]. Diaziridines, on the other hand, have been found to readily undergo oxidation into diazirines, which are important in photoaffinity labelling experiments in vivo and in vitro due to their propensity to undergo photochemical reactions to generate carbenes $[23,24]$.

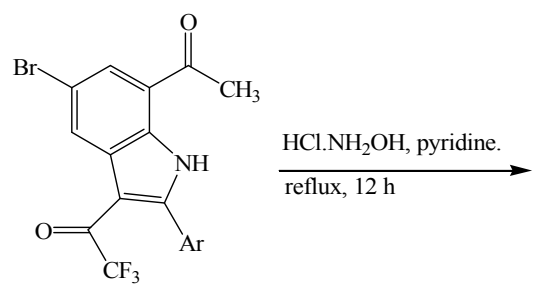

1a-d

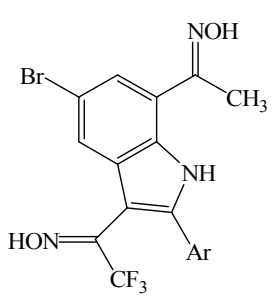

2a-d

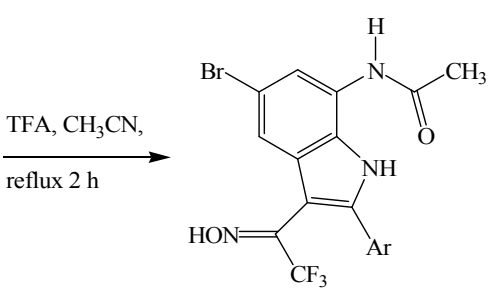

3a-d

Scheme 1. Synthesis of the 7-acetamido-2-aryl-5-bromo-3-(trifluoroacetyloxime)indoles 3a-d. 
Table 1. Percentage yields of compounds 2 a-d and 3a-d.

\begin{tabular}{cccc}
\hline Compound & Ar & \%Yield of 2 & \% Yield 3 \\
\hline a & $\mathrm{C}_{6} \mathrm{H}_{5}-$ & 77 & 73 \\
b & $4-\mathrm{FC}_{6} \mathrm{H}_{4-}$ & 77 & 70 \\
$\mathbf{c}$ & $3-\mathrm{ClC}_{6} \mathrm{H}_{4-}$ & 66 & 70 \\
$\mathbf{d}$ & $4-\mathrm{MeOC}_{6} \mathrm{H}_{4}-$ & 74 & 65 \\
\hline
\end{tabular}

A single crystal of $\mathbf{3} \mathbf{d}$ was obtained by slow evaporation of a chloroform solution, and the molecular structure of compounds 3a-d was confirmed by X-ray diffraction analysis (CCDC No.: 1822506).

\subsection{X-ray Single Crystal Structure of $\mathbf{3 d}$}

Chloroform as a solvate has previously been found to play an important role in crystal packing [25] and analysis of the crystal structure of $\mathbf{3 d}$ revealed that it co-exists with a chloroform solvate in the ratio 3:1 (Figure 1). There is evidence of existence of halogen bonding between chloroform molecule and 3d. The 2-aryl ring of $\mathbf{3 d}$ is twisted out of plane of co-planarity to avoid steric interaction with the trifluoroacetyl oxime moiety with torsion angles $C(9)-C(8)-C(10)-C(11)$ and $\mathrm{N}(1)-\mathrm{C}(8)-\mathrm{C}(10)-\mathrm{C}(15)$ of $-140.0^{\circ}$ and $-144.2^{\circ}$, respectively. There is intramolecular hydrogen bonding between the amide oxygen and hydrogen atom attached to the indole nitrogen $(\mathrm{N}-1$; Figure 2$)$ with $\mathrm{N}(1)-\mathrm{H}(1) \cdots \mathrm{O}(3)$ bond distance of $2.00 \AA$ and bond angle $\angle($ DHA $)=135^{\circ}$ (Table 2). The molecules are also bound together by several intermolecular hydrogen bonds (Figure 2). There is evidence of indole stacking in the crystal structure of $3 \mathbf{d}$ with distances of $3.4 \AA$ and $4.0 \AA$ between the planes and the centroids, respectively (Figure 3 ). However, $\pi$-stacking has not been observed before in the crystal structure of the analogous 5-methoxy-1-methylindole-3-carboxaldehyde oxime derivative [26]. The crystal structure of $\mathbf{3} \mathbf{d}$ also revealed the presence of the aromatic $\mathrm{CH}-\pi$ interactions with distances C $\cdots$ centroid $=2.6 \AA$ and angle $\mathrm{CH} \cdots$ centroid $=158^{\circ}$ (Figure 4 ). $\mathrm{CH}-\pi$ hydrogen bond has been found to play significant role in crystal packing, the structure of clathrates, solid-state reactions, and drug design [27]. Strong intermolecular hydrogen bonding exists between the amide oxygen of one molecule and the hydroxyl proton of the other with $\mathrm{O}(2)-\mathrm{H}(2) \cdots \mathrm{O}(3)$ bond distance and bond angle of $1.64 \AA$ and $170^{\circ}$, respectively. Intermolecular hydrogen bonding also exists between the amide proton of one molecule and oxygen atom of the oxime moiety of another molecule with bond distance and bond angle of $\mathrm{N}(3)-\mathrm{H}(3) \cdots \mathrm{O}(2)=2.17 \AA$ and $177^{\circ}$, respectively. The structure also presents 6-membered rings formed through halogen bonds $(\mathrm{C}-\mathrm{Br} \cdots \mathrm{Br}$ ) with $\mathrm{Br} \cdots \mathrm{Br}$ distances of $3.7 \AA$ (Figure 5). Some examples of similar situations in which bromine plays an important role in crystal packing have been described in the literature $[28,29]$. Crystal data and structure refinement for compound $\mathbf{3} \mathbf{d}$ are represented in Table 3.

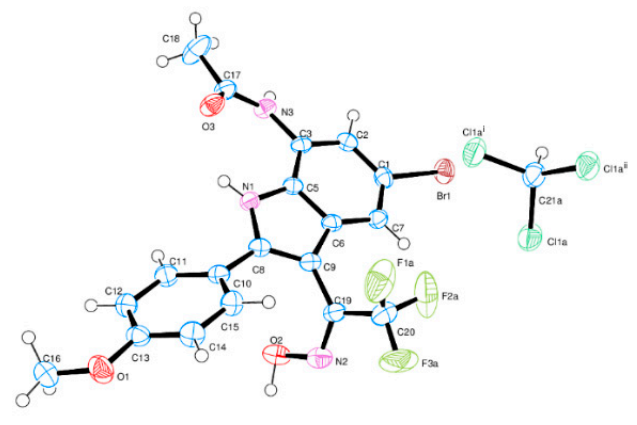

(a) XRD

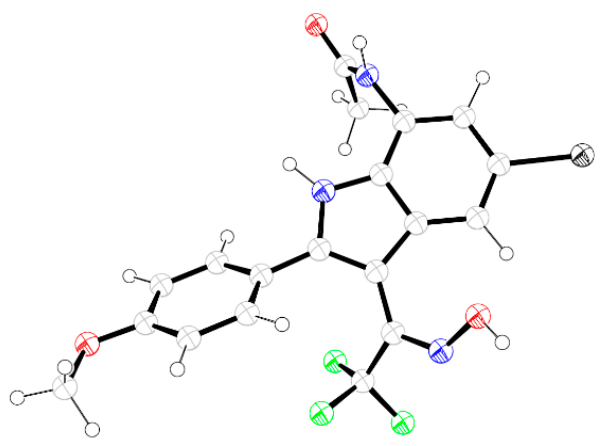

(b) Computed

Figure 1. (a) The Oak Ridge Thermal Ellipsoid Plot (ORTEP) diagram of $\mathbf{3 d}$ showing crystallographic labelling. Displacement ellipsoids are drawn at the 50\% probability level; (b) A view of the optimized structure of $\mathbf{3 d}$ from density functional theory (DFT) calculations. 


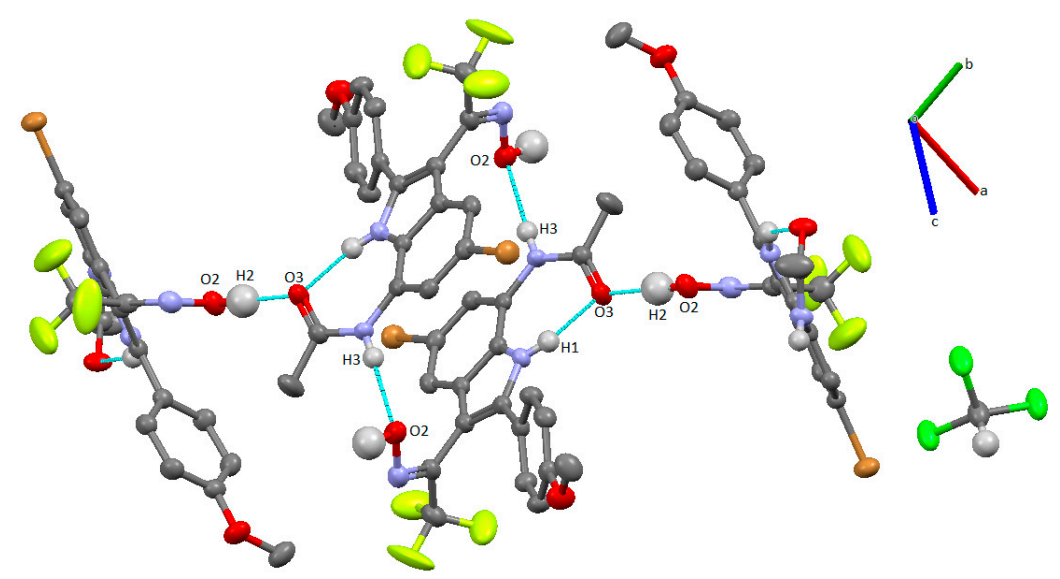

Figure 2. Compound 3d showing intra- and intermolecular hydrogen bonding.

Table 2. Selected hydrogen bonding interactions in compound 3d.

\begin{tabular}{ccccc}
\hline D-H $\cdots \mathbf{A}$ & $\mathbf{d}(\mathbf{D}-\mathbf{H}) \mathbf{d}$ & $\mathbf{d}(\mathbf{H} \cdots \mathbf{A})$ & $\mathbf{d}(\mathbf{D} \cdots \mathbf{A})$ & $\angle$ (DHA) \\
\hline $\mathrm{N}(1)-\mathrm{H}(1) \cdots \mathrm{O}(3)$ & $0.85(3)$ & $2.00(2)$ & $2.668(2)$ & $135(2)$ \\
$\mathrm{N}(3)-\mathrm{H}(3) \cdots \mathrm{O}(2) \# 3$ & $0.80(3)$ & $2.17(3)$ & $2.968(2)$ & $177(2)$ \\
$\mathrm{O}(2)-\mathrm{H}(2) \cdots \mathrm{O}(3) \# 4$ & $0.96(4)$ & $1.64(4)$ & $2.597(2)$ & $170(3)$ \\
\hline
\end{tabular}

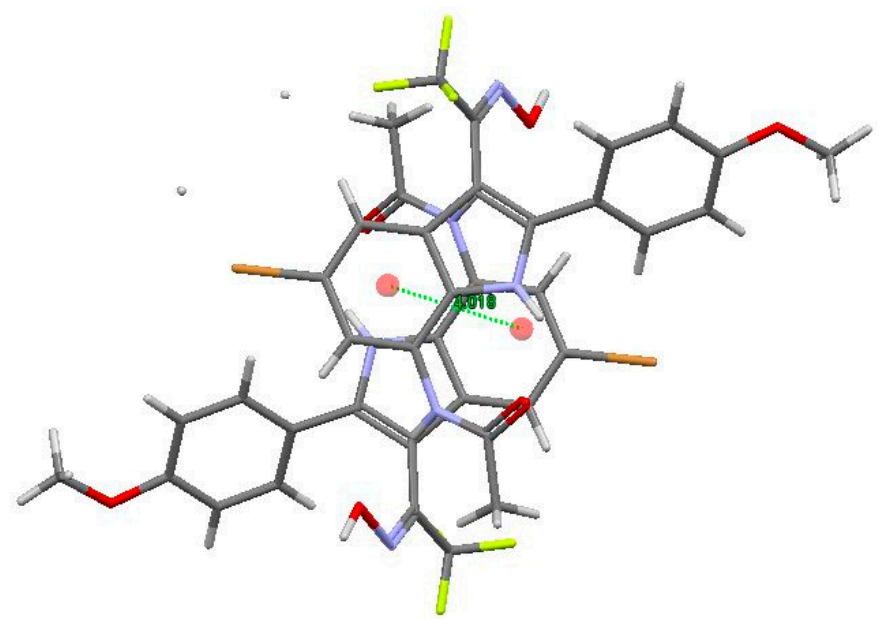

Figure 3. Indole stacking in the crystal structure of $\mathbf{3 d}$.

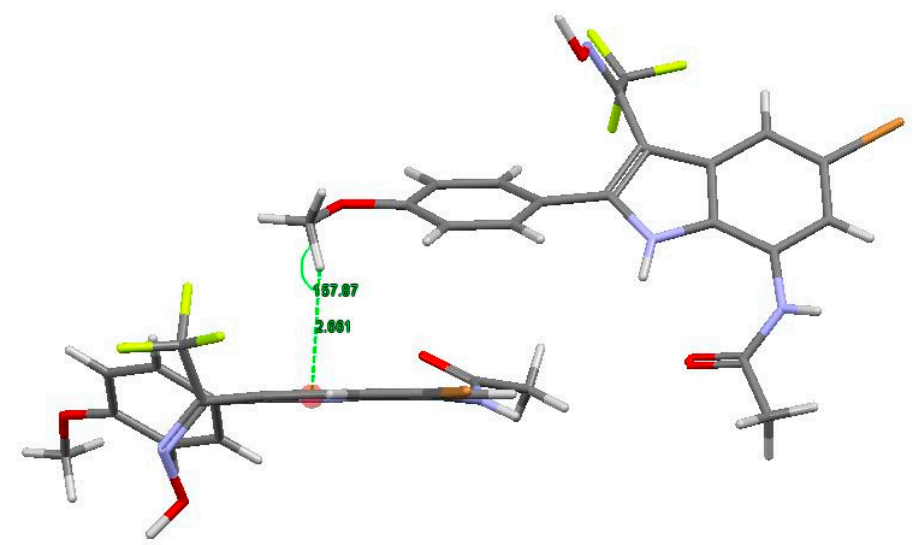

Figure 4. Structure of $3 \mathrm{~d}$ showing $\mathrm{CH}-\pi$ bond interaction. 


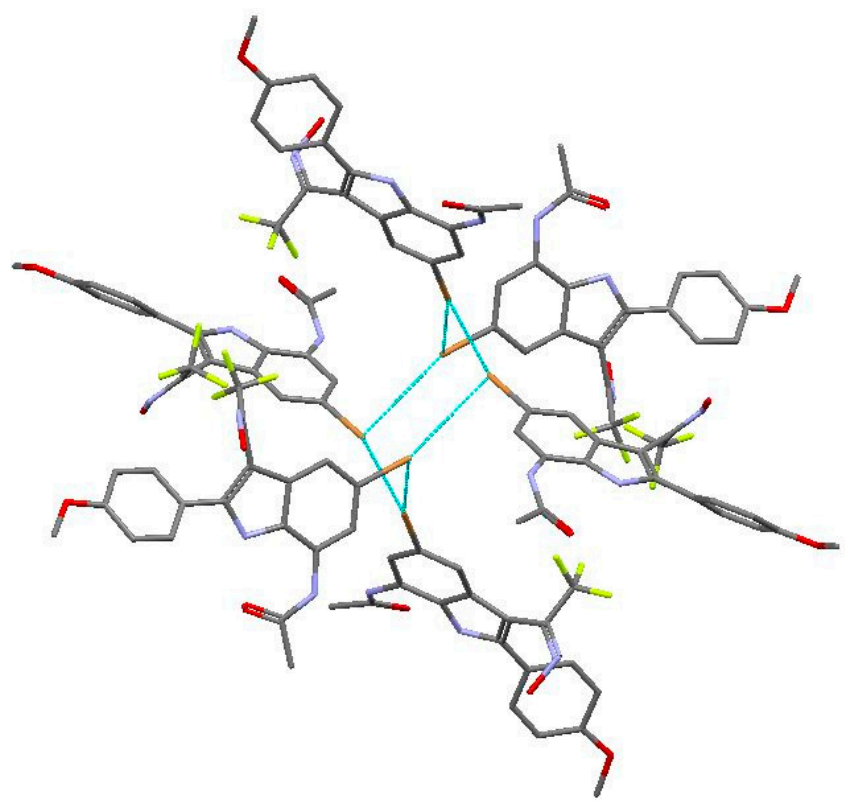

Figure 5. 6-membered rings formed through halogen bonds $(\mathrm{C}-\mathrm{Br} \cdots \cdot \mathrm{Br})$ between molecules of $\mathbf{3 d}$.

Table 3. Crystal data and structure refinement for compound $3 \mathbf{d}$.

\begin{tabular}{|c|c|c|c|}
\hline \multicolumn{4}{|c|}{ CCDC No.: 1822506} \\
\hline Formula & $\mathrm{C}_{19} \mathrm{H}_{15} \mathrm{BrClF}_{3} \mathrm{~N}_{3} \mathrm{O}_{3}$ & Refinement method & Full-matrix least-squares on $F^{2}$ \\
\hline Formula weight & 469.02 & Data/restraints/parameters & $3916 / 58 / 329$ \\
\hline Temperature & $173(2) \mathrm{K}$ & Measured reflections & 122613 \\
\hline Wavelength & $0.71073 \AA$ & $\theta_{\min } / \theta_{\max }$ & $2.804 / 25.499^{\circ}$ \\
\hline Crystal system & Trigonal & $R_{\text {int }}$ & 0.0588 \\
\hline Space group & $\mathrm{R}-3: \mathrm{H}$ & Goodness-of-fit on $F^{2}$ & 1.027 \\
\hline Unit cell dimensions & $\begin{array}{c}\mathrm{a}=25.1614(13) \AA \\
\mathrm{b}=25.1614(13) \AA \\
\mathrm{c}=17.3032(9) \AA \\
\alpha=90^{\circ} \\
\beta=90^{\circ} . \\
\gamma=120^{\circ}\end{array}$ & $\begin{array}{l}\text { Final } R \text { indices } \\
\quad[\mathrm{I}>2 \sigma(\mathrm{I})]\end{array}$ & $\begin{array}{c}R_{1}=0.0282 \\
w R_{2}=0.0681\end{array}$ \\
\hline Volume & $9486.9(11) \AA^{3}$ & $R$ indices (all data) & $\begin{array}{c}R_{1}=0.0366 \\
w R_{2}=0.0729\end{array}$ \\
\hline $\mathrm{Z}$ & 6 & Largest diff. peak/hole & $0.359 /-0.367$ e. $\AA^{-3}$ \\
\hline Density (calcd.) & $1.607 \mathrm{Mg} / \mathrm{m}^{3}$ & & \\
\hline Absorption coefficient & $2.129 \mathrm{~mm}^{-1}$ & & \\
\hline $\mathrm{F}(000)$ & 4596 & & \\
\hline Crystal size & $0.384 \times 0.063 \times 0.062 \mathrm{~mm}^{3}$ & & \\
\hline
\end{tabular}

\subsection{Optimized Geometry of $\mathbf{3 d}$}

The optimized structure of $\mathbf{3} \mathbf{d}$ is shown in Figure $1 \mathbf{b}$ above and was obtained by the density functional theory (DFT) method using hybrid functional Becke's three parameter nonlocal exchange functional with the Lee-Yang-Parr correlation function (B3LYP) and the 6-311G basis set. Some of the optimized parameters, namely, the bond lengths, bond angles, and torsion angles are given in Table 4 and they have been assigned in accordance with the XRD atomic numbering scheme given in Figure $1 \mathrm{a}$. The conformation of the 2-arylindole framework of the optimized structure of $\mathbf{3 d}$ in the gas phase resembles that of the XRD structure with a slight difference on the orientation of the acetamido and 3-trifluoroacetyloxime groups. These deviations are presumably due to the involvement of these groups in intermolecular interactions in the solid state (see Figure 2) in which case the molecules are linked by 
the crystal field along intermolecular interactions. There are no significant differences between the experimentally determined structural parameters and those predicted using the DFT method.

Table 4. Selected experimental and theoretical bond lengths $(\AA)$ and angles $\left(^{\circ}\right)$ of $3 \mathbf{d}$.

\begin{tabular}{|c|c|c|}
\hline Geometric Parameters & X-ray & DFT \\
\hline & \multicolumn{2}{|c|}{ Bond lengths (Å) } \\
\hline $\mathrm{C}(3)-\mathrm{N}(3)$ & $1.416(3)$ & 1.433 \\
\hline $\mathrm{C}(8)-\mathrm{N}(1)$ & $1.377(3)$ & 1.388 \\
\hline$C(8)-C(10)$ & $1.462(3)$ & 1.466 \\
\hline$C(9)-C(19)$ & $1.472(3)$ & 1.448 \\
\hline $\mathrm{C}(13)-\mathrm{O}(1)$ & $1.361(3)$ & 1.405 \\
\hline $\mathrm{C}(16)-\mathrm{O}(1)$ & $1.413(3)$ & 1.455 \\
\hline $\mathrm{C}(17)-\mathrm{O}(3)$ & $1.236(3)$ & 1.012 \\
\hline $\mathrm{C}(17)-\mathrm{N}(3)$ & $1.335(3)$ & 1.390 \\
\hline $\mathrm{C}(19)-\mathrm{N}(2)$ & $1.277(3)$ & 1.331 \\
\hline \multirow[t]{2}{*}{$C(19)-C(20)$} & $1.502(3)$ & 1.495 \\
\hline & \multicolumn{2}{|c|}{ Bond angles $\left({ }^{\circ}\right)$} \\
\hline $\mathrm{C}(5)-\mathrm{N}(1)-\mathrm{C}(8)$ & $110.2(18)$ & 110.4 \\
\hline$C(15)-C(10)-C(8)$ & $120.6(19)$ & 120.4 \\
\hline $\mathrm{N}(3)-\mathrm{C}(17)-\mathrm{C}(18)$ & $116.5(2)$ & 116.9 \\
\hline $\mathrm{N}(2)-\mathrm{C}(19)-\mathrm{C}(9)$ & $126.9(2)$ & 127.0 \\
\hline \multirow[t]{2}{*}{$\mathrm{C}(17)-\mathrm{N}(3)-\mathrm{C}(3)$} & $129.8(19)$ & 126.8 \\
\hline & \multicolumn{2}{|c|}{ Torsion angles $\left({ }^{\circ}\right)$} \\
\hline$N(1)-C(8)-C(10)-C(15)$ & $-144.2(2)$ & -145.0 \\
\hline $\mathrm{O}(3)-\mathrm{C}(17)-\mathrm{N}(3)-\mathrm{C}(3)$ & $-2.6(4)$ & -1.3 \\
\hline $\mathrm{C}(14)-\mathrm{C}(13)-\mathrm{O}(1)-\mathrm{C}(16)$ & $-177.8(2)$ & -177.4 \\
\hline
\end{tabular}

The HOMO (highest occupied molecular orbital) and LUMO (lowest unoccupied molecular orbital) are important factors mostly used as descriptors in Quantitative Structure Activity Relationship (QSAR) [30]. The HOMO and LUMO surfaces of compound 3d were computed at the B3LYP/6-311G level and these are represented in Figure 6. DFT calculations revealed that the HOMO is mainly localized on the 2-arylindole framework and the $\alpha$-trifluoromethylated ketoxime function and partially on oxygen atom of the methoxy group. The LUMO, on the other hand, is localized mainly on the aromatic framework and partially on the $\alpha$-trifluoromethylated ketoxime, methoxy, and the amide functions. The value of the energy separation between HOMO and LUMO is $-0.10476 \mathrm{eV}$ and this small energy gap could indicate that the title structure can be excited using minimal energy.

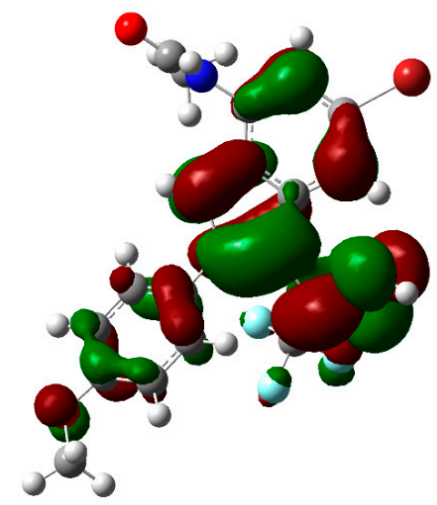

$\operatorname{HOMO}(-0.28560 \mathrm{eV})$

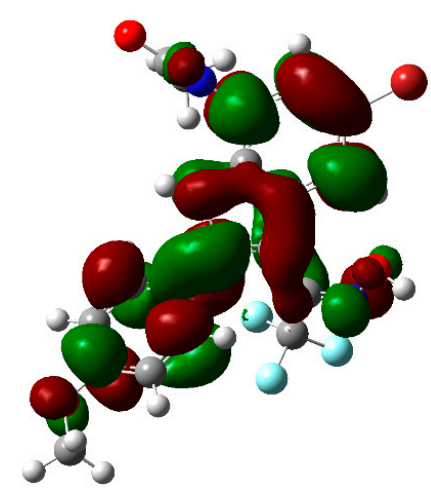

$\operatorname{LUMO}(-0.18084 \mathrm{eV})$

Figure 6. Frontier molecular orbitals of $3 d$ using the B3LYP /6-311++G(d,p) basis set. 


\section{Conclusions}

The diketoximes 2a-d and the 7-acetamido-2-aryl-3-(trifluoroacetyloxime)indoles 3a-d, were synthesized and characterized using a combination of spectroscopic techniques. The three-dimensional structure of compounds 3a-d was further confirmed using single crystal $\mathrm{X}$-ray diffraction on a representative compound $\mathbf{3 d}$. The crystal structure revealed the presence of strong intramolecular and intermolecular hydrogen bonds as well as aromatic $\mathrm{CH}-\pi$ and $\mathrm{C}-\mathrm{Br} \cdots \mathrm{Br}$, which play significant role in the crystal packing. The X-ray structure and the DFT optimized counterpart calculated by the B3LYP/6-311G basis set compare favourably and the optimized geometry reproduced the crystal structure parameters well. Since a strong hydrogen bond acceptor (e.g., acetyl, formyl or trifluoroacetyl group) at the C-3 position of the indole framework enhances anticancer activity $[5,6]$, the presence of a dual hydrogen bond donating and accepting ketoxime moiety in this position makes compounds 3 suitable candidates for evaluation of biological activity as potential anticancer agents to correlate between structural variation and cytotoxicity. Molecular docking (in silico) could be used to predict the hypothetical protein-ligand binding mode against tubulin or other relevant examples of enzyme kinases to guide further structure activity relationship (SAR). The $\alpha$-trifluoromethylated ketoxime moiety also represents suitable template for further transformation into the corresponding $\alpha$-trifluoromethylated amines or diazirines.

Funding: This research received no external funding.

Acknowledgments: The author is grateful to the University of South Africa and the National Research Foundation (NRF) in South Africa for financial assistance as well as the University of Stellenbosch Central Analytical Facility (CAF) for mass spectrometric analysis. X-ray data was acquired at the University of the Witwatersrand using the single-crystal diffractometer purchased through a grant from the NRF National Equipment Programme (UID: 78572). The author also thanks Mmakwena M. Mmonwa for technical assistance and Marole M. Maluleka for proofreading this manuscript.

Conflicts of Interest: There is no conflict of interest.

\section{References}

1. Abele, E.; Abele, R.; Dzenitis, O.; Lukevics, E. Indole and isatin oximes: Synthesis, reactions, and biological activity. Chem. Heterocycl. Compd. 2003, 39, 3-35. [CrossRef]

2. Bertolasi, V.; Gilli, G.; Veronese, A. Structures of E,E-3-(p-tolylimino)-2-butanone oxime and $E, Z$-4-( $p$-tolylimino)-2,3-pentanedione 3-oxime. An X-ray crystallographic investigation on bonding in oximes. Acta Crystallogr. Sect. B 1982, B38, 502-511. [CrossRef]

3. Desiraju, G.; Steiner, T. The Weak Hydrogen Bond-in Structural Chemistry and Biology; Oxford University Press: New York, NY, USA, 1999.

4. Hadzi, D.; Kidric, J.; Koller, J.; Mavrij, J. The role of hydrogen bonding in drug-receptor interactions. J. Mol. Struct. 1990, 237, 139-150. [CrossRef]

5. Watterson, S.H.; Dhar, T.G.M.; Ballentine, S.K.; Shen, Z.; Barrish, J.C.; Cheney, D.; Fleener, C.A.; Roleau, K.A.; Watterson, R.T.S.H.; Dhar, T.G.M.; et al. Novel indole-based inhibitors of IMPDH: Introduction of hydrogen bond acceptors at indole C-3. Bioorg. Med. Chem. Lett. 2003, 13, 1273-1276. [CrossRef]

6. Mphahlele, M.J.; Pabhoo, N. Synthesis, evaluation of cytotoxicity and molecular docking studies of the 7-acetamido substituted 2-aryl-5-bromo-3-trifluoroacetylindoles as potential inhibitors of tubulin polymerization. Pharmaceuticals 2018, 11, 59. [CrossRef] [PubMed]

7. Kool, E.T. Hydrogen bonding, base stacking, and steric effects in DNA replication. Annu. Rev. Biophys. Biomol. Struct. 2001, 30, 1-22. [CrossRef] [PubMed]

8. Mishra, S.K.; Suryaprakash, N. NMR research centre, solid state and structural chemistry, intramolecular hydrogen bonding involving organic fluorine: NMR investigations corroborated by DFT-based theoretical calculations. Molecules 2017, 22, 423. [CrossRef] [PubMed]

9. Cheng, G.; Wu, Q.; Shang, Z.; Liang, X.; Lin, X. Stereoselective transformations of $\alpha$-trifluoromethylated ketoximes to optically active amines by enzyme-nanometal cocatalysis: Synthesis of (S)-inhibitor of phenylethanolamine $N$-methyltransferase. Chem CatChem 2014, 6, 2129-2133. [CrossRef] 
10. Hu, H.; Wu, J.; Ao, M.; Wang, H.; Zhou, T.; Xue, Y.; Qiu, Y.; Fang, M.; Wu, Z. Synthesis, structure-activity relationship studies and biological evaluation of novel 2,5-disubstituted indole derivatives as anticancer agents. Chem. Biol. Drugs Des. 2016, 88, 766-778. [CrossRef] [PubMed]

11. Mphahlele, M.J.; Mmmonwa, M.M.; Choong, S.Y. Synthesis and evaluation of N-(3-trifluoroacetylindol-7-yl) acetamides for potential in vitro antiplasmodial properties. Molecules 2017, 22, 1099. [CrossRef] [PubMed]

12. Bruker, APEX-3, SAINT+; Version 6.02 (Includes XPREP and SADABS); Bruker AXS Inc.: Madison, WI, USA, 2016.

13. Sheldrick, G.M. A short history of SHELX. Acta Cryst. C 2015, 71, 3-8. [CrossRef] [PubMed]

14. Farrugia, L.J. ORTEP-3 for Windows-a version of ORTEP-III with a Graphical User Interface (GUI). J. Appl. Crystallogr. 2012, 45, 849-854. [CrossRef]

15. Spek, A.L. Structure validation in chemical crystallography. Acta Cryst. D 2009, 65, 148-155. [CrossRef] [PubMed]

16. Becke, A.D. Density-functional thermochemistry III. The role of exact exchange. J. Chem. Phys. 1993, 98, 5648-5652.

17. Lee, C.; Yang, W.; Parr, R.G. Development of the Colle-Salvetti correlation-energy formula into a functional of the electron density. Phys. Rev. B 1988, 37, 785-789. [CrossRef]

18. Krishnan, R.; Binkley, J.S.; Seeger, R.; Pople, J.A. Self-consistent molecular orbital methods. XX. A basis set for correlated wave functions. J. Chem. Phys. 1980, 72, 650-654.

19. Frisch, M.J.; Trucks, G.W.; Schlegel, H.B.; Scuseria, G.E.; Robb, M.A.; Cheeseman, J.R.; Scalmani, G.; Barone, V.; Mennucci, B.; Petersson, G.A.; et al. Gaussian 09, Revision A.01; Gaussian Inc.: Wallingford, CT, USA, 2009.

20. Honarparvar, B.; Govender, T.; Maguire, G.E.; Soliman, M.E.; Kruger, H.G. Integrated approach to structure-based enzymatic drug design: Molecular modeling, spectroscopy, and experimental bioactivity. Chem. Rev. 2013, 114, 493-537. [CrossRef] [PubMed]

21. Qu, J.; Kumar, N.; Alamgir, M.; Balck, D.S. A versatile synthetic route to $11 \mathrm{H}$-indolo[3,2-c]isoquinolines. Tetrahedron Lett. 2009, 50, 5628-5630. [CrossRef]

22. Strømgaard, K.; Saito, D.R.; Shindou, H.; Ishii, S.; Shimizu, T.; Nakanishi, K. Ginkgolide derivatives for photolabeling studies: Preparation and pharmacological evaluation. J. Med. Chem. 2002, 45, 4038-4046. [CrossRef] [PubMed]

23. Wartmann, T.; Lindel, T. L-Phototryptophan. Eur. J. Org. Chem. 2013, 2013, 1649-1652. [CrossRef]

24. Protasova, I.; Bulat, B.; Jung, N.; Bräse, S. Synthesis of diaziridines and diazirines via resin-bound sulfonyl oximes. Org. Lett. 2017, 19, 34-37. [CrossRef] [PubMed]

25. Allen, F.H.; Wood, P.A.; Galek, P.T.A. Role of chloroform and dichloromethane solvent molecules in crystal packing: An interaction propensity study. Acta Cryst. 2013, B69, 379-388. [CrossRef] [PubMed]

26. Janes, R.W.; Potter, B.S.; Naylor, M.A.; Ferguson, A.C.; Patel, K.B.; Stratford, M.R.L.; Wardman, P.; Evertt, S.A. 1-Methylindole-3-carboxaldehyde oxime derivatives. Acta Cryst. 2001, C57, 58-61. [CrossRef]

27. Nishio, M. CH/ $\pi$ hydrogen bonds in crystals. CrystEngComm 2004, 6, 130-158. [CrossRef]

28. Aakerōy, C.B.; Fasulo, M.; Schultheiss, N.; Desper, J.; Moore, C. Structural competition between hydrogen and halogen bonds. J. Am. Chem. Soc. 2007, 129, 13772-13773. [CrossRef] [PubMed]

29. Tero, T.-R.; Salorinne, K. The effect of halogen bonding on the packing of bromine-substituted pyridine and benzyl functionalized resorcinarene tetrapodants in the solid state. CrystEngComm 2012, 14, 7360-7367. [CrossRef]

30. Clare, B.W. Frontier orbital energies in quantitative structure-activity relationships: A comparison of quantum chemical methods. Theor. Chim. Acta 1994, 87, 415-430. [CrossRef]

(C) 2018 by the author. Licensee MDPI, Basel, Switzerland. This article is an open access article distributed under the terms and conditions of the Creative Commons Attribution (CC BY) license (http:/ / creativecommons.org/licenses/by/4.0/). 